\title{
Contingency Factors, Risk Management, and Performance of Indonesian Banks
}

\author{
Saiful \\ Dept. of Accounting, Bengkulu University \\ PO Box 38371A, Bengkulu, Indonesia \\ Tel: 62-736-21170Ｅ-mail: saifulak@yahoo.com
}

Received: Nov. 28, $2016 \quad$ Accepted: February 1, $2017 \quad$ Published: June 1, 2017

doi:10.5296/ajfa.v9i1.10372 URL: http://dx.doi.org/10.5296/ajfa.v9i1.10372

\begin{abstract}
The purpose of this study is to examine the effect of enterprise risk management (ERM) and credit risk management (CMR) on Indonesian bank performance. This study also investigates the moderating role of bank contingency factors on those impacts. By exploring purposive sampling method, 24 Indonesian public listed Banks were selected as the sample of this study for four years observations.

This study found ERM and CRM positively influence on Indonesian bank performance. This study also reported that the influencing of ERM on Bank performance will be stronger for large bank and the bank which operate in higher environmental uncertainty, higher complexity, and lower independent board monitoring. In contrast this study provide an empirical evidence on strangtern CRM-bank performance relationship will be exist for small bank and the bank which operate in lower environmental uncertainty, lower complexity, and higher independent board monitoring.
\end{abstract}

Keywords: Risk Management, Firm Performance, Environmental Uncertainty, Business Complexity, and Independent Board 


\section{Introduction}

Banks play a very important role in creating economic growth in both developed and developing countries. In order to achieve those objectives. banks must continuously be able to maintain the stability of their financial performance. However, it is not easy for banks to continuously report their superior performance in along time because of highly competitive business environment. The bank currently facing various risks that may affect the achievement of the bank's performance. For example, some of Indonesia top ten banks highlighted decline net profit in 2015 including the Bank Negara Indonesia (BNI), Panin Bank, and Bank Danamon. Its indicates there is not easy for Indonesian banks to maintain sustanability of their higher performance because of various risks.

Fraser and Kolari (2001) concluded that banking industries deal with credit, country, market, interest rate, liquidity, operational, legal and reputation risk. In addition Basel Committee on Banking Supervision (2000) define credit risk as the potential failing of banks borrower orcounter party to meet its obligations. Moreover, the committe highlighted that banks face credit risk sourced from loan and other various financial instruments, including acceptances, interbank transactions, trade financing foreign exchange transactions, financial futures, swaps, bonds, equities, options, and in the extension of commitments and guarantees, and the settlement of transaction. Thoses risks would have a negative impact on the bank's performance. Since the bank facing a variety of potential risks throughout the bank's operations, management must be able to implement an effective risk management to control and manage risk. Banks' managers should consider the best way to reduce risks. Gordon et al.(2009) describe management in any industries including banking must view and manage risk as firm fundamental concern based on a holistic perspective known as enterprise risk management (ERM) in addition Pagach and Warr (2011) state that ERM is a strategy that holistically evaluate and manage the risks. However, for banking industries credit risk should be given greater attention in risk management compared to other risks. Therefore, banks' managers should implement a holistic risk management (ERM) as well as specific credit risk management $(\mathrm{CRM})$ principles

Some previous studies highlighted that the implementation of ERM provide the postive impact to firm performance (e.g. Barton et al., 2002 \& Liebenberg \& Hoyt, 2003). Furthermore, Beasley et al. (2005) found that ERM promote the better operational performance. In addition, Miccolis and Shah (2000), Lam (2001), Meulbroek (2002) indicate that ERM can reduce the volatility of stock prices, reduced capital costs, increase efficiency, and create synergies. However, Rafika (2012) and Fitrianti (2013) found that ERM positively impact on firm value, and Gordon, et.al (2009) found the strengtern influencing of enterprise risk management on firm performance companies defend on the companies and environmental conditions.

In another persepective, banks should also focus on mitigating credit risk as inherent risk in their business activities through implementation CRM. Bank for International Settlements (Basel Committee on Banking Supervision, 2000) describes the credit risk as a potential lending or counter party will fail in repayment obligations. Credit risk is the greatest risk 
faced by commercial banks and a major cause of failure (Fraser \& Kolari. 2001; Angerer 2004).

The effective management of credit risk is a critical component of a comprehensive approach to risk management and essential to the long-term success banks. Al Shatti (2015) found that CRM which proxied by non performing loan ratio (NPL) positively effect on the performance of the Jordan commercial.banks In contrast, Poudel (2012 reported the negative relationship between CRM and financial performance of Nepal commercial banks. Ruth (2013) found the negatively relationship between CRM and firm performance, and independent board moderate that relationship.

Abiola (2014) found a positive (unusual) relationship between Non-performing loans (NPL) and bank's profitability. Its means the better credit risk management will be followed by lower bank performance. Adeusi, Akeke, Adebisi and Oladunjoye (2013) concluded that NPL is not effected on banks performance. Fan and Yijun (2014) found that there is a negative relationship between NPL and ROE and between NPL and ROA. However, the findings on year by year analysis demonstrate a fluctuating relationship between those variables dependent on the contigency factors such economic crisis.Kurawa and Garba (2014) provide additional evidence on a positive relationship between NPL and ROA Poudel (2012) found credit risk management indicators including NPL negatively affected banks' financial performance. Ogboi and Unuafe (2013) found sound credit risk management that measured by NPL is not affected on bank's financial performance.

However, according to the contingency theory, the organization's performance is a consequence of external factors such as environmental, organizational structure, corporate culture, and technological factors. Moreover, contingency theory states that organization must adapt a variety of contingent factors, such as organizational structure, environment, organizational size, and business strategy in achieving higher performance (Lawrence \& Lorsch, 1967). Meanwhile, Otley (1980) conclude that the stronger relationship between ERM and firm performance dependent on firm contextual factors. Therefore, contingency theory plays a very important role in explaining what factors are contributing to firm performance. In context of risk management-firm performance relationship, contingency factors need to be taken into account are: (1) the environment uncertainty (Tjahjadi, 2011), (2) complexity (Husaini, et. al. 2013), (3) firm size (Husaini et al. 2013), and independent board Monitoring (Beasley, et.al, 2005). So the purpose of this study is to investigate the moderating role of contengency (firm specific) factors on the influence of ERM and CRM on indonesian bank/s performance.

\section{Literature Review and Hypothesis Development}

\subsection{ERM and Bank Performance}

COSO (2004) defines ERM as “a process, affected by an entity's board of directors, management and other personnel, applied in strategy setting and across the enterprise, designed to identify potential events that may affect the entity, and manage risk to be within its risk appetite, to provide reasonable assurance regarding the achievement of entity 
objectives." While, The casuality Actuarial Society (CAS) defines ERM process of assessing, controlling, financial exploitation, and monitoring risks from various sources which aims to increase the short term and long termfirm value for all stakeholders. ERM encompasses aligning risk appetite and strategy, enhancing risk response decisions, reducing operational surprises and losses, identifying and managing multiple and cross-enterprise risks, seizing opportunities, and improving deployment of capital (Beasley, et al., 2005).

COSO (2004), explains that the effectiveness of an organization's ERM should be determined based on the achievement of four objectives ERM ie strategy, operations, compliance, and reporting. Some studies using those objective as conprehensive proxies for measuring implementation of ERM (for example see Gordon et al, 2009)

Barton et al (2002), Lam (2002, Liebenberg, (2003) proved that ERM implementation can improve the performance of the company. Miccolis and Shah (2000), Lam (2001), AND Meulbroek (2002) highlighted that ERM can reduce the volatility of stock prices, reduced capital costs, increase efficiency, In context of indonesia Rafika (2012) and Fitrianti (2013), found that the positively relationship between ERM and firm value. So we come up with hypothesis:

\section{H1: ERM positively effect on bank performance}

\subsection{CRM and Bank Performance}

According to Indonesian Central Bank Regulation Number: 11/25 / PBI / 2009, the credit risk is the risk of the failure of the debtor and / or other parties to meet obligations to the bank. Meanwhile, Investopedia defines credit risk as a potential lost of loan principal and interest for the borrower's failure to fulfill obligations in accordance with the loan contract. Most previous studies on credit risk measured those potential lost through non performing loan proxy (see Ratih, 2013; Al Shatti,2015).

The effective management of credit risk is a critical component of a comprehensive approach to risk management and essential to the long-term success of any banking organisation. Credit risk can arise from the various bank businesses. Ratih (2013) use of non-performing loans as a proxy for measuring credit risk management efectiveness Therefore credit risk management will positively affect the profitability of the banking ( $\mathrm{Li}$ and Zou in Alshatti, 2015). Furtheremore, Al Shatti, (2015) measure credit risk management using some indicators, namely the capital adequency ratio, the ratio of credit facilities, net facilities ratio, leverage ratio and non-performing loans.

Credit risk management is commonly proxied by the non-performing loans (NPL), because it shows the bank's ability to manage their loans. The high NPL will lead to a decrease in profit (Almilia and Herdiningtyas, 2005). The lower the NPL ratio, the lower the credit risk, and the higher of credir risk management successfully. Low credit risk will affect the the higher bank's financial performance and market. This is because the lower credit risk will give confidence to the owners and other stakeholders on the success of the bank implement credit risk management well. Poudel (2012) states that credit risk management is proxied by NPL negatively affect the financial performance of banks in Nepal. So we come up with 
hypothesis:

\section{H2: Credit risk management positive effect on bank performance}

\subsection{Risk Management, environment uncertainty, and Bank Performance}

Gerloff et al. (1991) states that the environment uncertainty consist of contingencies and perceptual aspects. Aspects of contingencies related to the understanding of the environment and organizational adjustment to the reality of the environment. While the perceptual aspect relates to a process orientation, comprehension, interpretation, and scanning of the environment. Gong et al. (2009) measures the uncertainty of the environment by using Cash Flow Volatility. Gordon et. al. (2009) measures the uncertainty of the environment with a combination of: (1) market (coefficient of variation of sales), (2) technology (coefficient of variation of $\mathrm{R} \& \mathrm{D}$ costs and capital expenditures divided by total assets), (3) Income (coefficient of variation of income before taxes). risks to be borne by the company will vary depending on environmental uncertainty to be faced. The higher the environmental uncertainty facing companies will affect the relationship between the risk management systems with the performance of this. Gordon, et.al. (2009) find environmental uncertainties affect the relationship between the implementation of ERM and firm performance. So we come up with hypothesis

\section{H3: Environmental Uncertainty moderates ERM-bank performance relationship.}

Many economic theories state that the credit cycle and failures are still common with empirical conditions of uncertainty in the cycle. Lesmana (2006) suggested that the need for a credit risk management model specific to anticipate the credit risk of failure of the borrower to repay the loan principal and interest. The credit risk management model should be appropriate to the conditions of environmental uncertainty. When banks operating at a high environmental uncertainty impacting on the increased likelihood of a borrower experiencing financial difficulty and fail to repay the loan, bank managers must implement a good credit risk management. In that condition, the effect of credit risk management on firm performance will be stronger. So we come up with hypothesis

\section{H4: Environmental Uncertainty moderates CRM-bank performance relationship.}

\subsection{Risk Management, Complexity, and Bank Performance}

The complexity of the company can be proxied by the number of business segments owned by a company (Doyle et.al. 2007). Meanwhile, Merchant (1981) concludes that highly diversified companies will require intensively internal control than the less diversified and decentralized companies. This is due to the complexity of such operations which pose more risks to be faced by the companies. Doyle et al. (2007) highlighted that the material weaknesses internal control occurs in companies with more complex operations. Hoyt et al. (2006) found that the high complexity companies need to implement better ERM, in order to improve their financial performance. We therefore conclude that the company with a high level of complexity will strengthen affect ERM implementation on firm performance. So we come up with hypothesis 
H5: bank complexity moderates ERM-bank performance relationship.

Credit risk is the assessment of the quality of the bank's operational risk management. Credit risk of them comes from bad loans, if large amounts will affect every corner of the bank's operations. Bad credit will hamper banking operations because bank profits obtained from the difference between deposits and lending interest (Elizabeth, 2009). credit risk will increase when the bank has a high complex or relatively broad diversification. in this condition should menerapan bank with good credit risk management in order to achieve optimum performance. So we come up with hypothesis

H6: bank complexity moderates CRM-bank performance relationship.

\subsection{Risk Management, Size, and Bank Performance}

The relationship between firm size and organizational structure has been a major consideration in the organization theory literature (Lawrence dan Lorsch, 1967). In addition, the accounting scholars also conclude that firm size is an important factor when considering the design and use of management control systems. Hoyt et al. (2006) found firm size is positively related to the the level risk management implementation. Beasley et al. (2005) showed that organization size positively related to the risk management implementation phase. Merchant (1981) argues that the growth of the organization raises communication and control escalation. So organization size will affect risk management - firm performance relationship. So we come up with hypothesis:

H7: bank size moderates ERM-bank performance relationship.

Rachdi, et. al. (2003) found that small size banks assume lower credit risk, so there is no incentive to implemented intensive credit risk management. Moreover, Ranjan and Dahl (2003) states that the bigger the bank, the smaller the rate of non-performing loans. So management needs to implement an effective credit risk management to reduce the risk of the loans in order to improve bank performance. So we come up with hypothesis

\section{H8: bank size moderates CRM-bank performance relationship}

\subsection{Risk Management, Independent Board, and Bank Performance}

Enterprise Risk Management as a strategy to manage the risks that can reach all parts of the company, not in spite of the existence of an independent commissioner who oversees the effort to control the risks that have been applied. Kleffner et al. (2003) suggests that the main factor underlying the adoption of ERM strategy firms in Canada was a drive of the board of directors. COSO (2004) also argues that the board of directors plays an important role in ERM implementation strategy. Beasley et al. (2005) suggested that independent directors on the board is positively related to the stage of implementation of ERM. In addition, Gordon et al. (2009), concluded the relationship between ERM and the performance of the company depends on the monitoring of the board of directors. So we come up with hypothesis:

H9: Independent board moderates ERM-bank performance relationship.

Dannon (2009) states that the internal governance mechanism including independent board 
role more effective in explaining bank risk. Moreover, Pathan (2009) found that independent board monitoring could contribution to reduction of various banking risks. Since credit risk can be metigated by independent board monitoring, credit management will not be strong contribution to increase bank performance. So we come up with hypothesis:

H10: Independent board moderates CRM-bank performance relationship.

\section{Research Method and Model}

\subsection{Population and Sample}

The populations in this study are all banking companies listed in Indonesia Stock Exchange (IDX) from 2010 until 2013. The samples in this study were selected by using purposive sampling method where the selection of samples taken in accordance with the criteria of the samples described in chapter previous. From several samples into the population there are some companies that are not used as samples because they do not meet the criteria. 24 of 31 banking companies have met the sample's criteria of this study or 96 observations in four (4) years.

\subsection{Definition and Measurement of Variables}

\subsubsection{Bank Performance (BP)}

There are two approaches that commonly employed in measuring firm performance i.e. financial accounting based measures (FAB) such as return on asset (ROA), return on equity (ROE), and return on sales (ROS), financial market based measures (FMB) such as stock return, market to book ratio, and Tobin-Q.

This study measures the bank performance using ratio of return on assets (ROA) to adjust the Indonesian central bank regulation on guidelines for Calculation of Financial Ratios:

$$
\mathrm{BP}=\frac{\text { Profit before tax }}{\text { Total asset }} \times 100 \%
$$

\subsubsection{Enterprise Risk Management}

Enterprise risk management (ERM) is calculated using ERM index (ERMI) that developed by Gordon, et al. (2009) based on COSO ERM objectives, namely strategy, operations, reporting, and compliance.

$$
\text { ERMI }=\Sigma \text { Strategy }+\Sigma \text { Operation }+\Sigma \text { Reporting }+\Sigma \text { Compliance }
$$

Strategy refers to the way the company positions itself against the competition in the market. Its means that the greater the income received by a company relative to the average industry income, the better strategy of that company or the higher ERM implementation, so.

$$
{\text { Strategy }{ }_{l}=}_{\sigma_{\text {Revenue }}}
$$

Note 
Revenue $_{i}$

: revenue bank $\mathrm{i}$ in year $\mathrm{t}$

$\mu_{\text {Revenue }}$

: evarege revenue all banks in year $\mathrm{t}$

$\sigma_{\text {Revenue }}$

: standard deviation revenue all banks in year $\mathrm{t}$

Another approach to measure a success strategic is based on competitive advantage of a bank in reducing systemic risk through diversification strategy compared to other banks (Thompson, 1984).

$$
\text { Strategy }_{2}=\quad \frac{\Delta \beta_{i}-\mu_{\Delta \beta}}{\sigma_{\Delta \beta}} \text {. }
$$

$\begin{array}{ll}\text { Note } & : \\ \Delta \beta_{i} & :-\left(\beta_{i} \text { year } \mathrm{t}-\beta_{i} \text { year } \mathrm{t}_{-1}\right) \\ \beta_{i} & : \text { beta bank } \mathrm{i} \\ \mu_{\Delta \beta} & : \text { Average all bank } \Delta \beta \text { in year } \mathrm{t} \\ \sigma_{\Delta \beta} & : \text { standard deviation } \Delta \beta \text { all bank }\end{array}$

Operating efficiency can be measured as an input-output relationship in the process of operating bank (Banker et al. 1989). The greater the output at a certain level of input or lack of inputs for a given level of output indicates better operating efficiency. So turnover of assets defined as income on total assets is one measure of the efficiency of operation (Kiymaz, 2006),

$$
\text { Operation }_{1}=\quad \frac{\text { Revenue }}{\text { Total Asset }}
$$

The second measurement for the operating ratio is determined by the income on the number of employees of the bank.

$$
\text { Opertioni }_{2}=\frac{\text { Revenue }}{\text { Number of Employees }}
$$

Reporting refers Reliability Reporting: Illegal earnings management, financial restatements, and financial fraud are the obstacle in the achievement of reliable financial statements (Cohen et al. 2004). reliability of reporting is proxied by the three dimensions are easily observed: namely: material weaknesses, the auditor's opinion, and restatements.

$$
\text { Reporting }_{1}=(\text { Material weakness })+(\text { Auditor Opinion })+(\text { Restatement })
$$

Reporting $_{1}$ obtains a value -1 for each component reliability include (1) the disclosure of material weaknesses in the annual report, (2) the audit report with an unqualified opinion, and (3) announced the restatement in year $t$, and the value 0 if otherwise,

The second measure of the reliability of bank reporting is using the relative proportion of 
absolute normal accruals divided by the sum of the absolute accrual normal and abnormal accruals.

Abnormal accruals are measured using cross-sectional Jones (1991) model of accrual measurement, as described in Defond and Subramanyam (1998) and Herawaty (2008). Calculation of total accruals are measured as the difference between profit and operating cash flows using the formula:

$$
T A=\text { net income }- \text { net operating cash flows }
$$

To compose a total accrual becomes abnormal and normal accrual then calculated with the following steps.

$$
\begin{gathered}
\frac{T A_{i t}}{A_{i t-1}}=\alpha_{0}+\alpha_{1}\left[\frac{1}{A_{i t-1}}\right]+\alpha_{2}\left[\frac{\left(\Delta O R_{i t}-\Delta R e c_{i t}\right)}{A_{i t-1}}\right]+\alpha_{3}\left[\frac{P P E_{i t}}{A_{i t-i}}\right]+e_{i t} \\
N D A_{i t}=\alpha_{1}\left[\frac{1}{A_{i t-1}}\right]+\alpha_{2}\left[\frac{\left(\Delta O R_{i t}-\Delta R e c_{i t}\right)}{A_{i t-1}}\right]+\alpha_{3}\left[\frac{P P E_{i t}}{A_{i t-i}}\right] e_{i t} \\
\frac{D A_{i t}}{A_{i t-1}}=\frac{T A_{i t}}{A_{i t-1}}-\left\{\alpha_{1}\left[\frac{1}{A_{i t-1}}\right]+\alpha_{2}\left[\frac{\left(\Delta O R_{i t}-\Delta R e c_{i t}\right)}{A_{i t-1}}\right]+\alpha_{3}\left[\frac{P P E_{i t}}{A_{i t-i}}\right]\right\} e_{i t} \\
D A_{i t}=T A_{i t}-N D A_{i t}
\end{gathered}
$$

\begin{tabular}{|c|c|c|}
\hline$\alpha_{0}$ & : & Constant \\
\hline$\alpha_{1-} \alpha_{3}$ & : & Regression Coefficient \\
\hline$T A_{i t}$ & : & Total Acrual Bank i in year $t$ \\
\hline$D A_{i t}$ & . & Discresionary accrual Bank $\mathrm{i}$ in year $\mathrm{t}$ \\
\hline$N D A_{i t}$ & & Nondiscresionary accrual Bank $\mathrm{i}$ in year $\mathrm{t}$ \\
\hline$A_{i t-1}$ & & Total asset Change Bank i in year $\mathrm{t}$ \\
\hline$\Delta O R_{i t}$ & & Operating revenue change Bank $\mathrm{i}$ in year $\mathrm{t}$ \\
\hline$\Delta R e c_{i t}$ & & Receivable (loan) change Bank $\mathrm{i}$ in year $\mathrm{t}$ \\
\hline$P P E_{i t}$ & & Fixed Asset plus accumulated depreziation Bank $\mathrm{i}$ in year $\mathrm{t}$ \\
\hline$e_{i t}$ & & error Bank $\mathrm{i}$ in year $\mathrm{t}$ \\
\hline
\end{tabular}

Note:

OLS (ordinary least squares) was used to obtain the coefficients of each variable above. The value of the coefficient $\alpha$ of equation (9) is put back into the equation (10) to get the value of normal accruals (NDA). Furthermore, abnormal accruals (DA) is computed by inputting the coefficient $\alpha$ of equation (10) into the equation (11).

If the actual value of the normal and abnormal accruals has been obtained, the next step is to calculate the value of the reliability of reporting. Reliability of reporting is measured by using the following formula: 


$$
\text { Reporting }_{2}=\frac{\mid \text { Normal Accrual } \mid}{\mid \text { Normal Accrual }|+| \text { Abnormal Accrual } \mid}
$$

Compliance: O'Keefe, et. al. (1994) found evidence that firm compliance can be increased with an increase in audit fees. Thus, compliance in this study measured by the auditor fee for financial statement audit, certification, check the individual accounts and consolidated, review due-diligence, agreed procedures (for example, confirmation of compliance with specific contractual agreements), as well as compliance and consulting tax, using the following equation:

$$
\text { Compliance }_{1}=\frac{\text { Auditor Fee }}{\text { Total Asset }}
$$

\subsubsection{Credit Risk Management}

Management of credit risk in this study is proxied by the reversal of the non-performing loan ratio. This is because the higher non-performing loan (NPL) indicates the worse the credit risk management, so that this study did reversal NPL value by multiplying by negative1. The formula used to calculate credit risk management are as follows:

$$
C R M=\frac{\text { Ksubstandard loans }+ \text { doubtful loans }+ \text { Bad loans }}{\text { Total Loan }} \times 100 \% \times(-1)
$$

\subsubsection{Environmental uncertainty}

This research uses Gong et al. (2009) approach in measuring environmental uncertainty by using Cash Flow Volatility, which is formulated as follows:

$$
\mathrm{EUC}=(\text { Operating Cash Flows }+\Delta \text { Operating Cash Flows }) / \text { Total Asset })
$$

\subsubsection{Bank complexity}

Bank complexity is the number of business segments owned by a bank (Doyle \&Mcvay 2007):

$$
\mathrm{BC}=\Sigma \text { Business Segments }
$$

\subsubsection{Bank Size}

Bank size can be measured by total assets (Sudjoko and Soebiantoro, 2007). The greater bank total assets, the greater the bank size. So:

$$
\mathrm{BS}=(\mathrm{Ln}) \text { Total Asset }
$$

\subsubsection{Independent Board}

Fama and Jensen (1983) stated that non-executive director (independent directors) can act as a mediator in disputes between managers and oversee internal management policy and provide advice to management. The number of independent directors should be able to ensure that the monitoring mechanism run in accordance with applicable regulations. The formula in calculating the independent directors, namely: 
$I B=\frac{\text { Independent Board Members }}{\sum \text { all boad members }}$

\subsection{Data Analysis Techniques}

In order to test the hypotheses of this study, five regression models has been developed as follows:

$$
\begin{gathered}
\mathrm{BP}_{\mathrm{it}}=\alpha+\beta_{1} \mathrm{ERM}_{\mathrm{it}}+\beta_{2} \mathrm{CRM}_{\mathrm{it}}+\mathrm{e}_{\mathrm{it}} \\
\mathrm{BP}_{\mathrm{it}}=\alpha+\beta_{1} \mathrm{ERM}_{\mathrm{it}}+\beta_{2} \mathrm{CRM}_{\mathrm{it}}+\beta_{3} \mathrm{EUC}_{\mathrm{it}}+\beta_{4} \mathrm{ERM} \times \mathrm{EUC}_{\mathrm{it}}+\beta_{5} \mathrm{CRM}_{\mathrm{it}} \mathrm{X} \mathrm{EUC}_{\mathrm{it}}+\mathrm{e}_{\mathrm{it}} \\
\mathrm{BP}_{\mathrm{it}}=\alpha+\beta_{1} \mathrm{ERM}_{\mathrm{it}}+\beta_{2} \mathrm{CRM}_{\mathrm{it}}+\beta_{3} \mathrm{FC}_{\mathrm{it}}+\beta_{4} \mathrm{ERM} \times \mathrm{FC}_{\mathrm{it}}+\beta_{5} \mathrm{CRM}_{\mathrm{it}} \times \mathrm{FC}_{\mathrm{it}}+\mathrm{e}_{\mathrm{it}} \\
\mathrm{BP}_{\mathrm{it}}=\alpha+\beta_{1} \mathrm{ERM}_{\mathrm{it}}+\beta_{2} \mathrm{CRM}_{\mathrm{it}}+\beta_{3} \mathrm{SIZE}_{\mathrm{it}}+\beta_{4} \mathrm{ERM} \times \mathrm{SIZE}_{\mathrm{it}}+\beta_{5} \mathrm{CRM}_{\mathrm{it}} \times \mathrm{SIZE}_{\mathrm{it}}+\mathrm{e}_{\mathrm{it}} \\
\mathrm{BP}_{\mathrm{it}}=\alpha+\beta_{1} \mathrm{ERM}_{\mathrm{it}}+\beta_{2} \mathrm{CRM}_{\mathrm{it}}+\beta_{3} \mathrm{IB}_{\mathrm{it}}+\beta_{4} \mathrm{ERM} \times \mathrm{IB}{ }_{\mathrm{it}}+\beta_{5} \mathrm{CRM}_{\mathrm{it}} \times \mathrm{IB}_{\mathrm{it}}+\mathrm{e}_{\mathrm{it}}
\end{gathered}
$$

Note :

$\mathrm{BP}_{\mathrm{it}} \quad$ : Bank i performance in year $\mathrm{t}$, as measured by ROA

$\alpha$

: Constant

$\beta_{1}-\beta_{5} \quad$ : Regressions Coeffisient

$\mathrm{ERM}_{\mathrm{it}} \quad$ : Enterprise Risk Management Index

$\mathrm{CRM}_{\mathrm{it}} \quad$ : Credit Risk Management measured by Non Performing Loan bank i in year $\mathrm{t}$

$\mathrm{EUC}_{\text {it }} \quad:$ Bank i Cash Flow Volatility in year $\mathrm{t}$

$\mathrm{BC}_{\mathrm{it}} \quad:$ Bank i complexity in year $\mathrm{t}$

SIZE $_{\text {it }} \quad:$ Bank i size in year $\mathrm{t}$

$\mathrm{KI}_{\text {it }} \quad$ : Bank i Independent board in year $\mathrm{t}$

\section{The findings}

\subsection{Statistic Descriptive}

A statistic description of variables that included in this study is presented in table 1. Table 1 shows that on average ERM index score is -0.33 with maximum score is 3.31 and the minimum score is $-5,31$. It indicates that some Indonesian listed Banks have been effectively implemented ERM system. In term of CRM, on overal Indonesian listed bank have no effectively adopted better credit risk management. Table 1 also shows that Indonesian listed bank operate in not so complexity, well business environment, and better independent board 
monitoring. On average indonesian listed bank highlighted lower net profit aruond $2.16 \%$ of total assets, even some bank reported loss.

Table 1. Statistic Descriptive

\begin{tabular}{lcccc}
\hline Variables & Min & Max & Mean & Std. Dev \\
\hline BP & $-7,58$ & 5,15 & 2,16 & 1,68 \\
ERM & $-5,31$ & 3,31 & $-0,33$ & 1,53 \\
CRM & $-0,02$ & $-6,25$ & $-1,59$ & 1,35 \\
EUC & $-0,34$ & 0,45 & 0,01 & 0,15 \\
FC & 2,00 & 8,00 & 3,97 & 1,28 \\
SIZE & 28,08 & 34,23 & 31.11 & 1,75 \\
IB & 0,25 & 1,00 & 0,57 & 0,12 \\
\hline
\end{tabular}

\subsection{Correlation Analysis}

Firstly, this study analyzed the correlation among independent and moderating variables in order to detect multicolinearity problem. Hair, Black, Babin, Anderson, and Tatham (2006) stated that multicolinearity problem occurs since the correlation among independent and moderating variables is 0.90 and higher. Table 2 presents the correlation matrix among independent variables and between independent and dependent variables. ERM is positively significant correlated to CRM ( $\mathrm{r}=0.259$, $\mathrm{p}$-value $<0.05), \mathrm{BC}(\mathrm{r}=0.479$, $\mathrm{p}$ value $<0.01)$, BS $(\mathrm{r}=0.372, \mathrm{p}$ value $<0.01)$ and IB $(\mathrm{r}=0.479, \mathrm{p}$ value $>0.05)$ but ERM negatively not significant related to EUC $(r=-0.020, p$ value $>0.05)$. This result indicated that there is no multicolinearity problem occurred in this study.

Secondly, this study analyzed the correlation between independent and dependent variables in order to determine the relationship between independent and dependent variables induvidually. This found that BP is positively significant associated with ERM $(r=0.345, p$ value $<0.01)$ and CRM $(\mathrm{r}=0.353$, $\mathrm{p}$ value $<0.01)$. BP is also postively significant correlated two moderating variables i.e. $\mathrm{BC}(\mathrm{r}=0.347, \mathrm{p}$ value $<0.01)$ and $\mathrm{BS}(\mathrm{r}=0.489, \mathrm{p}$ value $<$ 0.01). This findings indicate that an individual ERM and CRM positively influence indonesian listed bank performance.

Table 2. Pearson Correlation

\begin{tabular}{llllllll}
\hline & BP & ERM & EUC & BC & BS & IB & CRM \\
BP & 1 & & & & & & \\
ERM & $0.345^{* * *}$ & 1 & & & & & \\
EUC & -0.088 & -0.020 & 1 & & & & \\
BC & $0.347 * * *$ & $0.479 * * *$ & -0.005 & 1 & & & \\
BS & $0.489 * * *$ & $0.372 * * *$ & 0.027 & $0.441 * * *$ & 1 & & \\
IB & -0.113 & 0.116 & -0.091 & -0.016 & -0.166 & 1 & \\
CRM & $0.353 * * *$ & $0.259 * *$ & -0.119 & 0.188 & 0.195 & -0.185 & 1 \\
\hline$* * *$ Represents statistical significance at the 1\% level (two-tailed test) & & & \\
**Represents statistical significance at the 5\% level (two-tailed test) & & &
\end{tabular}




\subsection{Hypothesis Testing}

Table 3 consists of the five regression models results: The first model using to test hypotheses 1 and 2 (direct influencing of ERM and CRM to BP). The second model using to test hypotheses 3 and 4 (moderating role of EUC on influencing of ERM and CRM to BP). The third model using to test hypotheses 5 and 6 (moderating role of $\mathrm{BC}$ on influencing of ERM and CRM to BP). The second model using to test hypotheses 3 and 4 (moderating role of EUC influencing of ERM and CRM to BP). The forth model using to test hypotheses 7 and 8 (moderating role of BS on influencing of ERM and CRM to BP). The fifth model using to test hypotheses 9 and 10 (moderating role of IB on influencing of ERM and CRM to BP).

Based on the regression results in Table 3 model 1, the R Square 0.194 and significance p-value of $F<0.01$ indicate the model is fit and $19.4 \%$ variation of $\mathrm{BP}$ could be explained by ERM and CRM, This finds that by putting moderating variables in the model (EUC in model 2; BC in model 3; BS in model 4; and IB in model 5) the model still fitt and the explanation power increase, It indicate that moderating variable play an important role in explaining variation of indonesian listed bank performance.

\subsubsection{Risk Management and Bank Performance}

The regression results in Table 3 model 1 showed that ERM $(\beta=0.238$ and P-value $<0,01)$ and CRM $(\beta=0.281$ and $\mathrm{P}$-value $<0,01)$ are positively significant influence BP. This result suggested that $\mathrm{H} 1$ and $\mathrm{H} 2$ were supported.

The results of this study are consistent with Barton et al., (2002). Lam (2002), and Liebenberg (2003) who found that the ERM implementation can improve firm performance. This finding also indicates that bank with higher ERM practices followed by superior performance. This result is also align with Gustina (2015), Ruth (2013), Almilia and Herdiningtyas, (2005), and Poudel (2012) which states that credit risk management positively affects on firm performance.

\subsubsection{Risk Management, Environment Uncertainty, and Bank Performance}

The regression results in Table 3 model 2 showed that interaction ERM and EUC ( $\beta=1.633$ and P-value $<0,01$ ) is positively significant influence BP. However, interaction CRM and EUC $(\beta=-1.383$ and $\mathrm{P}$-value $<0,01)$ is negatively significant influence BP This result suggested that $\mathrm{H} 3$ and $\mathrm{H} 4$ were supported.

The results indicate that EUC strengtern the influencing of ERM and CRM on BP. The strengtern relationship between ERM and BP will be exist when EUC is high. Meanwhile strengtern relationship between CRM and BP will be exist when EUC is low

The results of this study are consistent with research Tseng et al. (2009), who obtained the result that the relationship between ERM and firm performance is highly dependent on environmental uncertainty factors. This argument is in line with the view that concluded that the environment is an important contextual factors that have very strong impact on the direction and strategy of the company (Hamel and Prahalad, 1994). 
The uncertainty of the environment is based on the basis of contingency theory which states that the relationship between two or more factors are very dependent on other factors (contingent) that can not be controlled by an organization (Otley, 1980). Uncertainty environment is always changing, causing the company to be able to adjust the implementation of ERM in accordance with the conditions of their environment. So the application of enterprise risk management to improve corporate performance more effective when high environmental uncertainty

Table 3. Summary Results of ERM, CRM, Bank Specific factors, and Bank Performance

\begin{tabular}{|c|c|c|c|c|c|}
\hline \multirow{2}{*}{ Variables } & \multicolumn{5}{|c|}{ Model } \\
\hline & 1 & 2 & 3 & 4 & 5 \\
\hline \multirow{2}{*}{ Constant } & 2.781 & 2.750 & 2.282 & -1.344 & 1.064 \\
\hline & $(14.369) * * *$ & $(15.023) * * *$ & $(3.343)^{* * *}$ & $(-0.427)$ & $(1.107)$ \\
\hline \multirow{2}{*}{ ERM } & 0.238 & 0.224 & -0.365 & -3.662 & 0.945 \\
\hline & $(2.801)^{* * *}$ & $(2.766)^{* * *}$ & $(-1.317)$ & $(-2.537)^{* *}$ & $(2.211)^{* *}$ \\
\hline \multirow{2}{*}{ CRM } & 0.281 & 0.279 & 0.281 & 4.429 & -1.177 \\
\hline & $(2.921) * * *$ & $(3.030) * * *$ & $(1.998)^{* *}$ & $(2.447) * *$ & $(-2.876) * * *$ \\
\hline ENVUC & & $\begin{array}{l}-1.884 \\
(-1.505)\end{array}$ & & & \\
\hline $\mathrm{FC}$ & & & $\begin{array}{c}0.641 \\
(0.490)\end{array}$ & & \\
\hline SIZE & & & & $\begin{array}{c}0.123 \\
(1.217)\end{array}$ & \\
\hline IB & & & & & $\begin{array}{c}2.706 \\
(1.669) *\end{array}$ \\
\hline ERM & & 1.633 & & & \\
\hline ENVUC & & $(3.055) * * *$ & & & \\
\hline CRM $\quad \mathrm{X}$ & & -1.383 & & & \\
\hline ENVUC & & $(-2.688) * * *$ & & & \\
\hline ERM X BC & & & $\begin{array}{c}0.115 \\
(1.992)^{* *}\end{array}$ & & \\
\hline CRM X BC & & & $\begin{array}{c}-0.099 \\
(-1.137)\end{array}$ & & \\
\hline ERM & & & & 0.120 & \\
\hline SIZE & & & & $(2.626) * * *$ & \\
\hline CRM $\mathrm{X}$ & & & & -0.137 & \\
\hline SIZE & & & & $(-2.304)^{* *}$ & \\
\hline ERM X IB & & & & & $\begin{array}{c}-1.245 \\
(-1.644) * * *\end{array}$ \\
\hline CRM X IB & & & & & $\begin{array}{c}2.266 \\
(3.628) * * * *\end{array}$ \\
\hline F-Stat & $11.046^{* * *}$ & $7.962 * * *$ & $6.525 * * *$ & $11.772 * * *$ & $8.014 * * *$ \\
\hline $\mathrm{R}^{2}$ & 0.194 & 0.309 & 0.268 & 0.398 & 0.310 \\
\hline
\end{tabular}


***Represents statistical significance at the 1\% level (two-tailed test)

**Represents statistical significance at the $5 \%$ level (two-tailed test)

*Represents statistical significance at the 10\% level (two-tailed test)

\subsubsection{Risk Management, Complexity, and Bank Performance}

The regression results in Table 3 model 3 showed that interaction ERM and $B C(\beta=0.115$ and $\mathrm{P}$-value $<0,05)$ is positively significant influence BP. However, interaction CRM and BC ( $\beta=-0.099$ and $\mathrm{P}$-value $>0,05)$ is negatively not significant influence BP This result suggested that $\mathrm{H} 5$ was supported and H6 was not supported. The results indicate that BC strengtern the influencing of ERM on BP. The strengtern relationship between ERM and BP will be exist when $\mathrm{BC}$ is high.

\subsubsection{Risk Management, Size, and Bank Performance}

The regression results in Table 3 model 4 showed that interaction ERM and BS ( $\beta=0.120$ and $\mathrm{P}$-value $<0,01)$ is positively significant influence BP. However, interaction CRM and EUC $(\beta=-0.137$ and $\mathrm{P}$-value $<0,05)$ is negatively significant influence BP This result suggested that $\mathrm{H} 7$ and $\mathrm{H} 8$ were supported. The results indicate that BS strengtern the influencing of ERM and CRM on BP. The strengtern relationship between ERM and BP will be exist in larger bank. Meanwhile strengtern relationship between CRM and BP will be exist in smaller bank.

\subsubsection{Risk Management, Independent Board, and Bank Performance}

The regression results in Table 3 model 4 showed that interaction ERM and IB ( $\beta=-1.245$ and $\mathrm{P}$-value $<0,01)$ is negatively significant influence BP. However, interaction CRM and IB $(\beta=2.266$ and $\mathrm{P}$-value $<0,01)$ is positively significant influence BP This result suggested that $\mathrm{H} 7$ and $\mathrm{H} 8$ were supported.

The results indicate that IB strengtern the influencing of ERM and CRM on BP. The strengtern relationship between ERM and BP will be exist in lower independent board monitoring bank. Meanwhile strengtern relationship between CRM and BP will be exist in hgher independent board monitoring bank.

\section{Conclusions}

The objectives of this study are to examine the influence enterprise (ERM) and credit (CRM) risk management on bank performance as well the moderating role of bank specific factor including bank environment uncertainty, conplexity, size, and independent board monitoring. This study found enterprise and credit risk management positively influence on indonesian listed bank performance. This study also reported that the influencing of ERM on Bank performance will be stronger since indonesian listed bank clasified as large bank and the bank operate in higher environmental uncertainty, higher complexity, and lower independent board monitoring. In contrast this study provide an empirical evidence on strangtern CRM-bank performance relationship will be occur when indonesian listed bank clasified as small bank and the bank operate in lower environmental uncertainty, lower complexity, and higher independent board monitoring. 
This results imply that ERM and CRM are complementer risk management components that impact to bank performance. However, the contingency or bank specific factors change the focus of those risk management practice. For example smaller bank should be implemented higher CRM than ERM. Moreover, bank with higher environmental uncertainty, higher business complexity, and ineffectively independent board role should highly into account to implement better ERM practices than CRM.

\section{References}

Abiola, I., \& Olausi, A.S. (2014). The Impact of Credit Risk Management on the Commercial Banks Performance in Nigeria. International Journal of Management and Sustainability, 3, 295-306.

Adeusi, S.O., Akeke, N.I., Adebisi, O.S., \& Oladunjoye, O. (2013). Risk Management and Financial Performance of Banks in Nigeria, Journal of Business and Management, 14, 52-56.

Almilia, Luciana Spica, \& Herdiningtyas. (2005). Analisis Rasio CAMEL Terhadap Prediksi Kondisi Bermasalah Pada Lembaga Keuangan Periode 2000-2002. Jurnal Akuntansi dan Keuangan, 7, 12-30.

Alshatti, Ali Sulieman. 2015. The Effect of Credit Risk Management on Financial Performance of The Jordanian Commercial Banks. Invesment Management and Financial Innovations, 12, 338-345

Angerr X. W. (2004). Empirical Studies on Risk Management of Investors and Banks. Dissertation. The Ohio State University.

Banker, R.D., Datar, S.M., \& Dan Kaplan, R.S. (1989).Productivity Measurement and Management Accounting. Journal of Accounting, Auditing and Finance, 4, 528-554.

Barton, T.T., Shenkir, W.C., \& Walker, T.L. (2002). Making Enterprise Risk Management Pay Off: How Leading Companies Implement Risk Management. Financial Time/Prentice Hall, Upper Saddle River, NJ.

Basel Committee on Banking Supervision. (2000). Principles for the management of credit Risk, $\mathrm{CH}-4002$ basel, Switzerland Bank for International Settlements.

Beasley, M.S., Clune, R., \& Dan Hermanson, D.R. (2005). Enterprise Risk Management: An Empirical Analysis of Factors Associated with the Extent of Implementation. Journal of Accounting and Public Policy, 24, 521-531. https://doi.org/10.1016/j.jaccpubpol.2005.10.001

Cohen, J., Krishnamoorthy, G., \& Dan Wright, A. (2004). The Corporate Governance Mosaic and Financial Reporting Quality. Journal of Accounting Literature, 23, 87-152.

COSO. (2004). Enterprise Risk Management-Intergrated Framework. Committee of Sponsoring Organizations of the Treadway Commission. New York.

Defond, M.L., \& Subramanyam, K.R. (1998). Auditor Change and Discresionarry Accrual. Journal of Accounting and finance, 25, 35-57. 
Doyle, J., Ge, W., \& Mcvay, S. (2007). Determinants of weaknesses in internal control over financial reporting. Journal of Accounting and Economics, 44, 193-223. https://doi.org/10.1016/j.jacceco.2006.10.003

Fama, E. F., \& Jensen, M. C. (1983). Separation of Ownership and Control. Journal of Law and Economics, 26, 301-325. https://doi.org/10.1086/467037

Fan, L., \& Yijun, Z. (2014). The Impact of credit risk management on profitability of commercial banks: A study of Europe, Umea School of Business and Economics: Available at: http://www.diva-portal. org.

Fitrianti, H. (2013). Pengaruh Enterprise Risk Management (ERM), Ukuran Perusahaan, Leverage dan Profitabilitas terhadap Nilai Perusahaan. Undergraduate Thesis of Faculty Economis and Business, Bengkulu University.

Fraser, D. R. B. E., \& Kolari, J. W. (2001). Commercial Banking : The Management of Risk. South-Western College Publishing, Cincinnati, Ohio.

Gerloff, E.A, Muir, N.K, \& Dan Bodensteiner, W.D. (1991). Three Components of Perceived Environmental Uncertainty: An Exploratory Analisys of The Effects of $\begin{array}{lllll}\text { Aggregation. Journal of } & \text { Management, } & \text { 17, }\end{array}$ https://doi.org/10.1177/014920639101700408

Gong, Guonjin. (2009). The Association Between Management Earnings Forecast Errors and Accruals. The Accounting Review, 84, 497-530. https://doi.org/10.2308/accr.2009.84.2.497

Gordon, L.A., \& V.K. Narayanan. (1984). Management Accounting Systems, Perceived Environmental Uncertainty and Organization Structure: An Empirical Investigation. Accounting Organizations and Society, 9, 259-285. https://doi.org/10.1016/0361-3682(84)90028-X

Gordon, L. A., Loeb, M. P., \& Tseng, C. Y. (2009). Enterprise risk management and firm performance: A contingency perspective. Journal of Accounting and Public Policy, 28, 301-327. https://doi.org/10.1016/j.jaccpubpol.2009.06.006

Hair, J., Anderson, R.E., Tatham, R.L., \& Black, W.C. (1998). Multivariate Data Analysis, Prentice Hall Internasional. Inc, New Jersey.

Herawaty, V. (2008). Peran Praktek Corporate Governance Sebagai Moderating Variable dari Pengaruh Earnings Management Terhadap Nilai Perusahaan. Jurnal Akuntansi dan Keuangan, 10, 97-108.

Husain., Saiful., Abdullah., \& Aisyah, Siti. (2013). Model Manajemen Risiko Perusahaan (Enterprise Risk Management) di Indonesia. Research Report, Universitas Bengkulu.

Jones, J.J. (1991). Earnings Management During Import Relief Investigation. Journal of Accounting Research, 29, 193-228. https://doi.org/10.2307/2491047

Kiymaz, H. (2006). The Impact of Announced Motives, Financial Distress, and Industry Affiliation on Shareholders' Wealth: Evidence from Large Sell-offs. Quarterly Journal of 
Business and Economics, 45, 69-89.

Kurawa, J.M., \& Garba, S. (2014). An Evaluation of the Effect of Credit Risk Management (CRM) on the Profitability of Nigerian Banks, Journal of Modern Accounting and Auditing, 10, 104-115.

Lam, J. (2001). The CRO is Here to Stay. Risk Management, 48, 16-22.

Lawrence, P.R., \& Lorsch, J.W. (1967). Organization and Environment: Managing Differentiation and Integration Boston, MA, Harvard University Press.

Lesmana, Iwan, (2006), Model Manajemen Risiko Kredit Komersial/ Korporasi Jangka Pendek Bank Umum Swasta Nasional, Doctoral Thesis, Universitas Gunadarma.

Merchant, KA. (1981). The Design of Corporate Budgeting System: Influences on Managerial Behaviour and Performances. The Accounting Review, 813-829.

Meulbroek, L.K. (2002). Integrated Risk Management for the Firm: A Senior Manager's Guide. (Online) (Accesed on February $\left.9^{\text {th }}, 2013\right)$. https://doi.org/10.2139/ssrn.301331

Miccolis, J., \& Shah, S. (2000). Enterprise Risk Management: An Analytic Approach. Tillinghast-Towers Perri

Miccolis, J., \& Shah, S. (2001). Risk Value Insights:Creating value through enterprise risk management-A practical approach for the insurance industry. Tillinghast-TowersPerrin Monograph

Ogboi, Ch., \& Unuafe, O.K. (2013). Impact of Credit Risk Management and Capital Adequacy on the Financial Performance of Commercial Banks in Nigeria, Journal of Emerging Issues in Economics, Finance and Banking, 2, 703-717.

O'Keefe, T.B., King, R.D., \& Dan Gaver, K.M. (1994). Audit Fees, Industry Specialization, and Compliance with GAAS Reporting Standards. Journal of Auditing, 13, 41-55.

Otley D. T. (1980). The Contingency Theory of Management Accounting : Achievement and Prognosis. Accounting, Organizational Behaviour Heinemann, London. https://doi.org/10.1016/0361-3682(80)90040-9

Pagach, D., \& Warr, R. (2011).The characteristics of firms that hire chief risk officers. $\begin{array}{lllll}\text { Journal of Risk } \quad \text { and } & \text { Insurance, } & 78 \text {, }\end{array}$ https://doi.org/10.1111/j.1539-6975.2010.01378.x

Pathan S. (2009). Strong Boards, CEO Power and Bank Risk-taking, Journal of Banking and Finance, 33, 1340-1350. https://doi.org/10.1016/j.jbankfin.2009.02.001

Poudel, R.P. (2012). The impact of credit risk management on financial performance of commercial banks in Nepal, International Journal of Arts and Commerce, 1, 9-15. Available at: http://www.ijac.org.uk/images.

Rafika, I. (2012). Pengaruh Good Corporate Governance terhadap Nilai Perusahaan dengan Enterprise Risk Management sebagai Variabel Intervening. Undergraduate Thesis of Faculty 
Economis and Business, Bengkulu University.

Rachdi, H., Trabelsi, M. A., \& Trad, N. (2013). Banking Governance and Risk: The Case of Tunisian Conventional Banks. Review of Economic Perspective, 13, 195-206. https://doi.org/10.2478/revecp-2013-0009

Ranjan, R and Dahl, S. D..(2003). Non-Performing Loan and Terms of Credit of Public Sector Banks in India: An Emperical Assessment. Reserve Bank of India. Occasional Papers, $24,81-121$.

Sujoko, \& Soebiantoro, U. (2007). Pengaruh Struktur Kepemilikan Saham, Leverage, Faktor Intern dan Faktor Ekstern terhadap Nilai Perusahaan. Jurnal Manajemen dan Kewirausahaan, 9, 47-67.

Tjahjadi, B. (2011). Hubungan Sistem Manajemen Risiko dengan Ketidakpastian Lingkungan dan Strategi serta Dampaknya terhadap Kinerja Organisasi. Majalah Ekonomi, XXI, 22-40. 